\title{
A Case of Hepatocellular Carcinoma Metastasis to the Dorsal Tongue
}

\author{
Dong Hyun Lee ${ }^{1}$, Jae Mahn Cho ${ }^{1}$, Woo Gyeong Kim² ${ }^{2}$ and Jun-Ook Park ${ }^{1}$ \\ ${ }^{1}$ Departments of Otolaryngology-Head and Neck Surgery, ${ }^{2}$ Pathology, Inje University College of Medicine, Haeundae Paik Hospital, \\ Busan, Korea
}

구강설을 침범한 전이성 간세포암종 1 예

이동현 ${ }^{1} \cdot$ 조재만 ${ }^{1} \cdot$ 김우경 $^{2} \cdot$ 박준욱 $^{1}$

인제대학교 의과대학 해운대백병원 이비인후과학교실, ${ }^{1}$ 병리학교실 ${ }^{2}$

\author{
Received January 18, 2016 \\ Revised March 10, 2016 \\ Accepted March 18, 2016 \\ Address for correspondence \\ Jun-Ook Park, MD, PhD \\ Department of Otolaryngology- \\ Head and Neck Surgery, \\ Inje University College of Medicine, \\ Haeundae Paik Hospital, \\ 875 Haeun-daero, Haeundae-gu, \\ Busan 48108, Korea \\ Tel $+82-55-797-2290$ \\ Fax $+82-55-797-2204$ \\ E-mail junook2000@paik.ac.kr
}

Hepatocellular carcinoma (HCC) is a common neoplasm, and its metastasis to the head and neck area is rare. We herein describe a unique case of HCC metastasis to the dorsal tongue. A 54-year-old male who was already diagnosed with $\mathrm{HCC}$ visited our hospital complaining of dysphagia and a progressively enlarging dorsal tongue mass. We operated to excise on the mass using $\mathrm{CO}_{2}$ laser including mucosal margin and deep margin. The diagnosis of HCC metastasis was confirmed immunohistochemically. After 2 weeks of follow-up, the patient did not exhibit any evidence of complication and could eat orally without any problem. Further treatment to the other metastatic lesion was rejected, and the patient was followed up for more than six months. We introduce this first case of metastatic HCC in the dorsal tongue. With the extended life expectancy of HCC patients, the incidence of rare metastasis is expected to increase. Korean J Otorhinolaryngol-Head Neck Surg 2017;60(4):183-6

Key Words Dorsum of tongue $\cdot$ Hepatocellular carcinoma $\cdot$ Metastasis.

\section{Introduction}

Hepatocellular carcinoma (HCC) is one of the most prevalent malignancies globally. HCC may indicate intrahepatic multiple occurrence and intrahepatic metastases. Extrahepatic metastasis of $\mathrm{HCC}$ takes place in about $30-50 \%$ of patients, and it is determined by HCC stages. The location of extrahepatic metastasis of $\mathrm{HCC}$ is mainly the lung. ${ }^{1 .}$ Extrahepatic metastases to various unusual sites from HCC have been informed of several case reports. ${ }^{2-4)}$ Metastatic malignancy of tongue is very rare, only one case of oropharyngeal tongue base, and we could not find any previous paper about HCC in dorsal surface of oral tongue in English literature. ${ }^{5)}$

This is an Open Access article distributed under the terms of the Creative Commons Attribution Non-Commercial License (http://creativecommons.org/licenses/by-nc/4.0) which permits unrestricted non-commercial use, distribution, and reproduction in any medium, provided the original work is properly cited.
The author reports on a case of an extrahepatic metastasis from $\mathrm{HCC}$ in the oral tongue.

\section{Case}

The patient involved was a 54-year-old male with HCC, chronic hepatitis B and liver cirrhosis. He underwent surgery at 16 months ago, segmentectomy of the liver, and Transarterial chemoembolization was implemented 5 times due to intrahepatic carcinoma recurrence. After 1 year that, $\mathrm{HCC}$ was spreaded to lung and brain. He then underwent wedge resection of lung and Gamma Knife surgery of the brain. After 4 month, he came to our department complaining of dysphagia and a progressively enlarging odorful dorsal tongue mass for 4 months. On physical examination, a pinkish lobulated hard mass measuring $2 \times 2 \mathrm{~cm}$ located on the dorsal of the tongue. 
No enlargement of the cervical lymph nodes was discovered (Fig. 1).

Computed tomography (CT) scans of the dorsum of tongue demonstrated a $1.8 \mathrm{~cm}$ well-defined, lobulated mass with good enhancement (Fig. 2A) and known intracranial metastatic mass at Lt. occipital lobe (Fig. 2B). A postoperative pos-

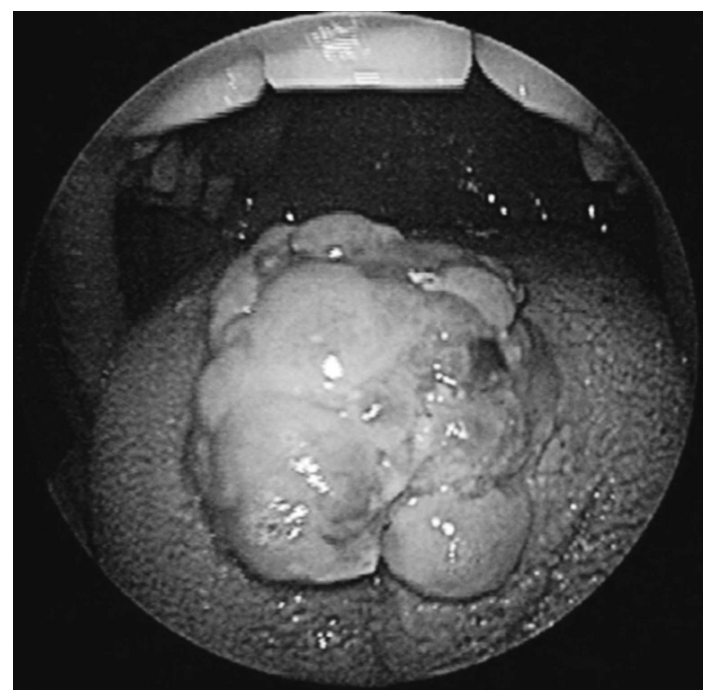

Fig. 1. A pinkish lobulated cancer located on the dorsal of the tongue.
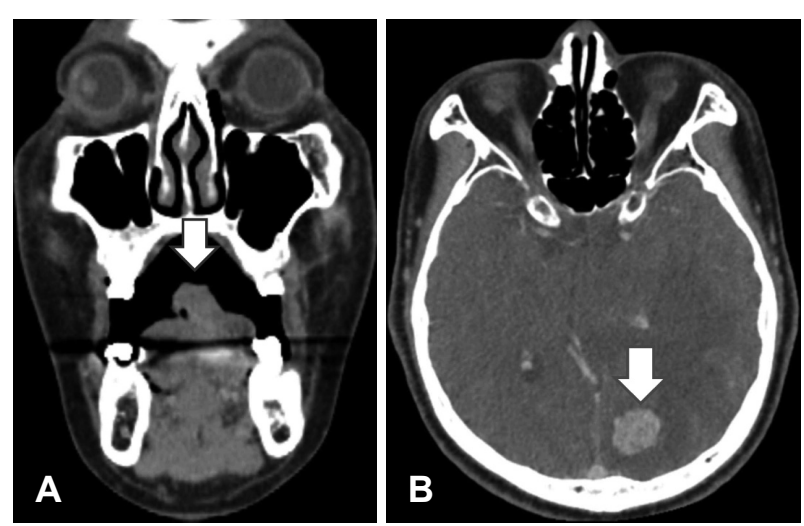

Fig. 2. Head and neck CT shows (A) lobulated dorsal tongue mass with enhancement (arrow) and (B) known intracranial metastatic mass at Lt., occipital lobe (arrow). itron emission tomography-CT showed bone, muscle (right buttock), brain, and multiple peritoneal seeding metastases probably from HCC. A preoperative workup showed that a liver function evaluation (AST $25 \mathrm{U} / \mathrm{L}$, ALT $39 \mathrm{U} / \mathrm{L}$ ) with coagulation profile were normal. But it showed an elevated PIVKA II (591 mAU/mL). We placed a Denhart mouth gag, approached the lesion intraorally, and exposed it by pulling and anchoring the tongue with Vicryl 4-0. We totally excised the mass using a $\mathrm{CO}_{2}$ laser; we included a 1-cm-deep cancerfree mucosal margin and a deep margin. The defect was closed with Vicryl 3-0. The patient was discharged 1 day later without any complications. Microscopically, the tumor exhibited a trabecular growth pattern, featuring plates of various thickness separated by sinusoid vascular spaces (Fig. 3A). The diagnosis of HCC metastasis was confirmed immunohistochemically, in that the tumor cells were positive for glypican-3 and hepatocyte-specific antigen (Fig. 3B). The minimum pathological cancer-free margin was $1 \mathrm{~cm}$.

Postoperative recovery was satisfactory. The patient left hospital 1 weeks later. After 2 weeks of follow-up the patient did not exhibit any evidence of complication and could eat orally without any problem. Further treatment to the other metastatic lesion was refused and just follow up was done by hepatologist for more than 6 months.

\section{Discussion}

The prevalence of $\mathrm{HCC}$ is world widely increasing. It takes possession about one quarter of a million deaths yearly, representing the third largest cause of cancer-related death in the world. ${ }^{1)}$ Most of these cases develop in the setting of cirrhosis secondary to hepatitis $\mathrm{B}$ and $\mathrm{C}$ infections or alcohol consumption. HCC is related to profound prognosis due to its aggressive behavior and its coexistence with decompensated hepatic functions. At the progressive stage and in recurrent cases, HCC has a higher potential for extrahepatic metas-

Fig. 3. A microscopic finding shows large polygonal tumor cells with eosinophilic granular cytoplasms, roundto-oval nuclei, and prominent nucleoli. Many mitoses and deposits of yellow-green pigments are evident $(\mathrm{H} \& \mathrm{E}$ stain, $\times 400)(\mathrm{A})$. The tumor cells are positive for hepatocyte specific antigen (HSA stain, $\times 400)(B)$.
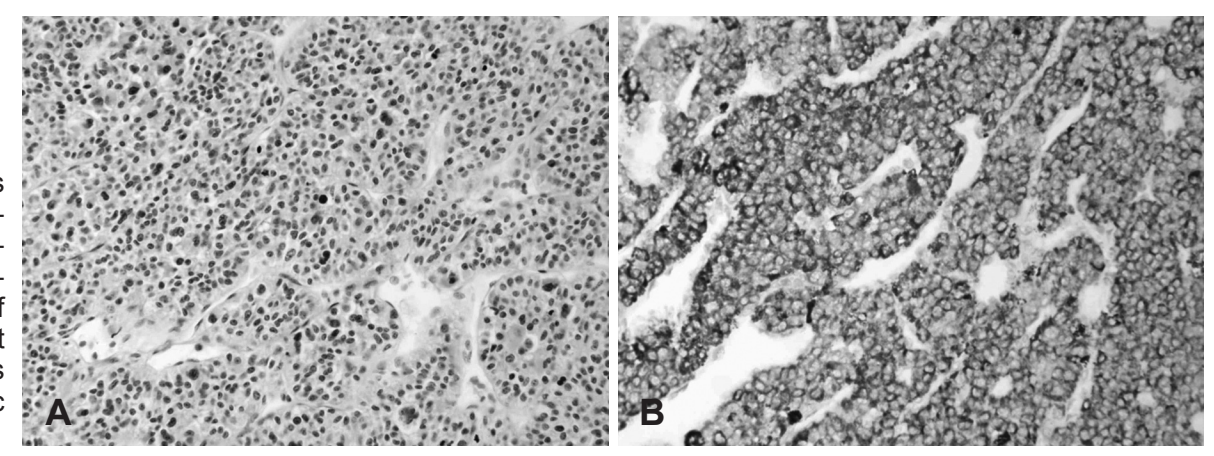
Table 1. Head and neck site of metastatic HCC in English literatures

\begin{tabular}{|c|c|c|c|c|c|}
\hline Age/sex & Site & Size & $\begin{array}{l}\text { Another site } \\
\text { metastasis }\end{array}$ & Treatment & Prognosis \\
\hline $55 / M$ & Gingiva & $2 \times 2 \mathrm{~cm}$ & $x$ & $\begin{array}{l}\text { Incisional biopsy } \\
\text { Chemotherapy }\end{array}$ & $\mathrm{N} / \mathrm{A}$ \\
\hline $56 / M$ & Lacrimal gland & $3.5 \times 3 \mathrm{~cm}$ & $x$ & $\begin{array}{l}\text { Excisional biopsy } \\
\text { TACE }\end{array}$ & After 1 year, HCC recurrence \\
\hline $65 / M$ & Tongue base & $2 \times 2 \mathrm{~cm}$ & $x$ & Excisional biopsy & After 3 month, pulmonary metastasis \\
\hline $69 / F$ & Skull & N/A & $x$ & $\begin{array}{l}\text { Excisional biopsy } \\
\text { Radiation therapy } \\
\text { TACE }\end{array}$ & N/A \\
\hline $78 / F$ & Gingiva & $2 \times 2 \mathrm{~cm}$ & $\begin{array}{l}\text { Skull } \\
\text { Lumbar vertebrae }\end{array}$ & Excisional biopsy & After 2 month, expired \\
\hline $70 / M$ & Mandible & $3 \times 2.5 \mathrm{~cm}$ & $x$ & Excisional biopsy & $N / A$ \\
\hline
\end{tabular}

N/A: not analysis, HCC: hepatocellular carcinoma, TACE: transarterial chemoembolization

tasis. ${ }^{6)}$ The lung, abdominal lymph nodes and the skeleton are the common sites of extrahepatic metastasis. Among these, lung is the most common and earliest detectable area of extraheptatic metastasis. HCC metastasis is not usually found in the head and neck area. Owing to the advancement of HCC treatment modalities, patients can survive for longer periods of time, allowing more opportunities for metastasis to occur and grow significantly. The existing paper has already reported isolated cases of metastases to the head and neck area (Table 1). ${ }^{1,2,6-9)}$ However, in endemic areas of hepatitis B such as Korea, the early detection program for HCC high-risk groups has made it rare for extrahepatic metastasis to be diagnosed before the primary tumor. ${ }^{10)}$ Lingual metastasis may be spreaded from systemic circulation, venous circulation or lymphatic circulation. Hematogenous spread appears to be the most common mechanism of distant metastasis. ${ }^{11)}$ Metastatic lesions can differ significantly in form. No recognized treatments for HCC metastases to the head-and-neck area have been established because such metastases are rare. In previous reports, the prescribed treatments have included surgery.

This case is the first one that HCC metastasizing to the dorsum of the tongue in the English literature as the clinical presentation of metastasis. Patients with an oral metastatic lesion accompanying with developed metastasis at other sites can be treated oral lesions surgically with palliative intent. ${ }^{12,13)}$ We also decide to do surgical excision of oral metastatic lesion to relieve symptom such as dysphagia and foul odor, his family members suffer from foul odor from the mass. In previous reports, six of seven patients were primarily found with only head-and-neck metastases (i.e., no other metastases), but two of them developed subsequent metastases within 1 year; data on the other patients are lacking. ${ }^{8,14,15)}$ The treat- ment of metastatic tumors requires careful deliberation, depending on the success or failure of treatment for the primary tumor, and on the existence of other sites of metastasis.

We introduce this first case of metastatic $\mathrm{HCC}$ in oral tongue. With the extended life expectancy of HCC patients, the incidence of rare metastasis is expected to increase in number for several years. The treatment guidelines for these conditions have not been well-studied and further studies to be needed.

\section{REFERENCES}

1) Terada $T$. Hepatocellular carcinoma metastatic to the gingiva as a first manifestation of hepatocellular carcinoma. J Maxillofac Oral Surg 2011;10(3):271-4.

2) Chen H, Li J, Wang L, Cong N, Shi C, Song J, et al. Hepatocellular carcinoma metastasis to the lacrimal gland: a case report. Oncol Lett 2014;8(2):911-3.

3) Choi HJ, Cho BC, Sohn JH, Shin SJ, Kim SH, Kim JH, et al. Brain metastases from hepatocellular carcinoma: prognostic factors and outcome: brain metastasis from HCC. J Neurooncol 2009;91(3): 307-13.

4) Wood AJ, Lappinga PJ, Ahmed I. Hepatocellular carcinoma metastatic to skin: diagnostic utility of antihuman hepatocyte antibody in combination with albumin in situ hybridization. J Cutan Pathol 2009;36(2):262-6.

5) Zegarelli DJ, Tsukada Y, Pickren JW, Greene GW Jr. Metastatic tumor to the tongue. Report of twelve cases. Oral Surg Oral Med Oral Pathol 1973;35(2):202-11.

6) Wang HY, Su CY, Lin JW, Chien CY. Base of the tongue metastatic cancer from hepatocellular carcinoma: a case report. Eur Arch Otorhinolaryngol 2004;261(10):531-3.

7) Chye CL, Lin KH, Ou CH, Sun CK, Chang IW, Liang CL. Acute spontaneous subdural hematoma caused by skull metastasis of hepatocellular carcinoma: case report. BMC Surg 2015;15:60.

8) Kanazawa H, Sato K. Gingival metastasis from primary hepatocellular carcinoma: report of a case and review of literature. J Oral Maxillofac Surg 1989;47(9):987-90.

9) Chin A, Liang TS, Borislow AJ. Initial presentation of hepatocellular carcinoma as a mandibular mass: case report and review of the literature. Oral Surg Oral Med Oral Pathol Oral Radiol Endod 1998; 86(4):457-60

10) Yoon SK, Chun HG. Status of hepatocellular carcinoma in South Korea. Chin Clin Oncol 2013;2(4):39. 
11) Elzouki AN, Elkhider H, Yacout K, Al Muzrakchi A, Al-Thani S, Ismail O. Metastatic hepatocellular carcinoma to parotid glands. Am J Case Rep 2014;15:343-7.

12) Hirshberg A, Shnaiderman-Shapiro A, Kaplan I, Berger R. Metastatic tumours to the oral cavity - pathogenesis and analysis of 673 cases. Oral Oncol 2008;44(8):743-52.

13) van der Waal RI, Buter J, van der Waal I. Oral metastases: report of
24 cases. Br J Oral Maxillofac Surg 2003;41(1):3-6.

14) Uchino K, Tateishi R, Shiina S, Kanda M, Masuzaki R, Kondo Y, et al. Hepatocellular carcinoma with extrahepatic metastasis: clinical features and prognostic factors. Cancer 2011;117(19):4475-83.

15) de Lope CR, Tremosini S, Forner A, Reig M, Bruix J. Management of HCC. J Hepatol 2012;56 Suppl 1:S75-87. 